\title{
Informal Financial Services, a Panacea for SMEs Financing? A Case Study of SMEs in the Ashanti Region of Ghana
}

\author{
Solomon Kwarteng Forkuoh*, Yao Li, Emmanuel Affum-Osei, Isaac Quaye \\ School of Management and Economics, University of Electronic Science and Technology of China (UESTC), \\ Chengdu, China \\ Email: "Forkuoh6@hotmail.com
}

Received 19 November 2015; accepted 18 December 2015; published 21 December 2015

Copyright (C) 2015 by authors and Scientific Research Publishing Inc.

This work is licensed under the Creative Commons Attribution International License (CC BY). http://creativecommons.org/licenses/by/4.0/

(c) (i) Open Access

\begin{abstract}
It has been established that Small and Medium enterprises (SMEs) play significant roles in the economic development of most countries in terms of job creation, innovation of new ideas, contribution to Gross Domestic Product and welfare, but the ability of SMEs to implement growth and developmental programs highly depend on access to external finance among other factors. Against this backdrop, the persistence citing of limited access to finance by SMEs in the Sub-Saharan African countries which places impediments on their business activities is worrisome to both the entrepreneurs and the State. In spite of several efforts by various governments and relevant institutions in rolling out support policies and initiatives in making access to external finance by SMEs more accessible, the problem still persist and SMEs maybe are yet to reap the full benefits from such initiatives. This research work does not rule out the fact that there exist alternative ways of financing SMEs outside the formal financial system, but this research focuses on the accessibility of the informal financial systems, with much emphasis on family and friends, their effectiveness, and how to meet the criteria for accessing the finance. The results show that SMEs that meet the requirements (trust, reputation, relation (family affiliation), religious affiliation,) of the lenders have easy access to alternative external finance, but the major challenges SMEs face when accessing the funds are the limited size of the loan and how to meet the demands of the lenders. On the lenders side, high defaulting rate is their major challenge. With careful modification without compromising the traditions involving the system, informal financial system will play significant role in providing the financial needs of SMEs.
\end{abstract}

\section{Keywords}

Informal Financial Systems, External Finance, SMEs, Access

\footnotetext{
${ }^{*}$ Corresponding author.
}

How to cite this paper: Forkuoh, S.K., Li, Y., Affum-Osei, E. and Quaye, I. (2015) Informal Financial Services, a Panacea for SMEs Financing? A Case Study of SMEs in the Ashanti Region of Ghana. American Journal of Industrial and Business Management, 5, 779-793. http://dx.doi.org/10.4236/ajibm.2015.512075 


\section{Introduction}

It has been established that Small and Medium enterprises play significant roles in the economic development of most developed and developing countries in terms of job creation, innovation of new ideas, contribution to Gross Domestic Product and welfare [1]-[7]. It is therefore in good taste to see various government and other institutions supporting SMEs in performance of such important role [8]. However, the ability of SMEs to improve its performance depends on investing, restructuring, and innovation, market expansion, recruiting, maintaining and motivating quality staff [9]-[11]. Access to external finance plays an important role in implementing all these actions so as to achieve the targeted growth and development [12], since most businesses rely heavily on external finance sources such as bank loans and equity finance in their business activities. As described by [13] that "Small firms are disproportionately handicapped by a lack of finance, but they receive a stronger boost in growth than large firms if financing is provided", but, when it comes to SMEs access to external finance in developing countries, there are market imperfections not only in times of crisis, but on an on-going basis as a fundamental structural issue, and this has been partially attributed to uncertainties and asymmetric information between the demand side (entrepreneur) and the supply side (financial intermediary) [14].

SMEs are strongly restricted in accessing the capital that they require growing and expanding, with nearly half of SMEs in developing countries rating access to finance as a major constraint Becks and [8].

This was direct opposite of what pertained among most SMEs in some European countries, where the dominant concern for MSMEs remained "finding customers" both during recession and the recovery, as only $30 \%$ of MSMEs in 2009 and 24\% in 2011 in EU cited access to finance as their major constraint [15], whiles over 70\% of SMEs in Africa cited access to finance as the dominant challenge to their business growth [8].

Recent research by [8] on financing SMEs in Africa countries attributes the limited access to finance from formal financial institutions among other factors to the fact that, Africa's financial systems are small, shallow and costly with limited outreach. This brings to fore the need to research into finding more effective ways of financing SMEs in developing countries, outside the formal financial system, taking advantages of tradition and cultural practices of the people. Since a positive correlation on impact of adequate finance and SMEs growth and development, it has been established with its accompanied important role in the economy of several countries [16].

The paper is structured as follows: Section 2 deals with the empirical literature review in relation to the hypothesis to be tested; Section 3 talks about the methodology adopted, the population and the sample size; it also explains the rationale for the choice of method and population. Section 4 and 5 handle the data analysis and conclusion respectively.

\section{Empirical Literature Review}

\subsection{SMEs Financing Difficulties}

In Africa, financial constraints together with corruption have been cited as the major obstacles to SMEs growth [17]. The African Development Bank (AfDB) confirmed in their recent research on access to finance by SMEs in Africa, and reported that, only 20\% of African SMEs had access to credit, and that only $9 \%$ of the investments SMEs make are funded by a bank. In contrast with what pertains in other developing countries in South America and Caribbean was direct opposite, 44\% of SMEs there have access to bank credit [18]. As a result, most SMEs in bridging the gap, usually finance their businesses from other sources such as reinvesting of profit, personal savings, family and friends and trade credits [19]. Ironically, these sources are not reliable and inadequate, since they are full of uncertainties and limited in supply.

The research conducted by Becks and Cull on SMEs financing in Africa countries revealed that, the use of bank loans in sub-Saharan Africa is lower than other developing regions of the world [8]. Their findings from all the three size groups of SMEs, which comprises of Micro, Small and Medium enterprises affirmed the earlier research findings by the Becks and other authors which showed that SMEs in Africa are less likely to have a loan than those outside Africa, with large firms in Africa even less likely to have a loan than mid-sized firms outside Africa [12]. Figure 1 below adopted from Becks and Cull (2014) shows the discrepancies in the use of external finance by various firms across the Globe including those in the sub-Saharan African countries.

The earlier work by [20], show that size, age and ownership are the most reliable predictors of firms' financing obstacles. The authors find that older, larger and foreign-owned firms' report of having easy access to external finance, the relationship is not only statistically significant, but also economically significant. The proba- 


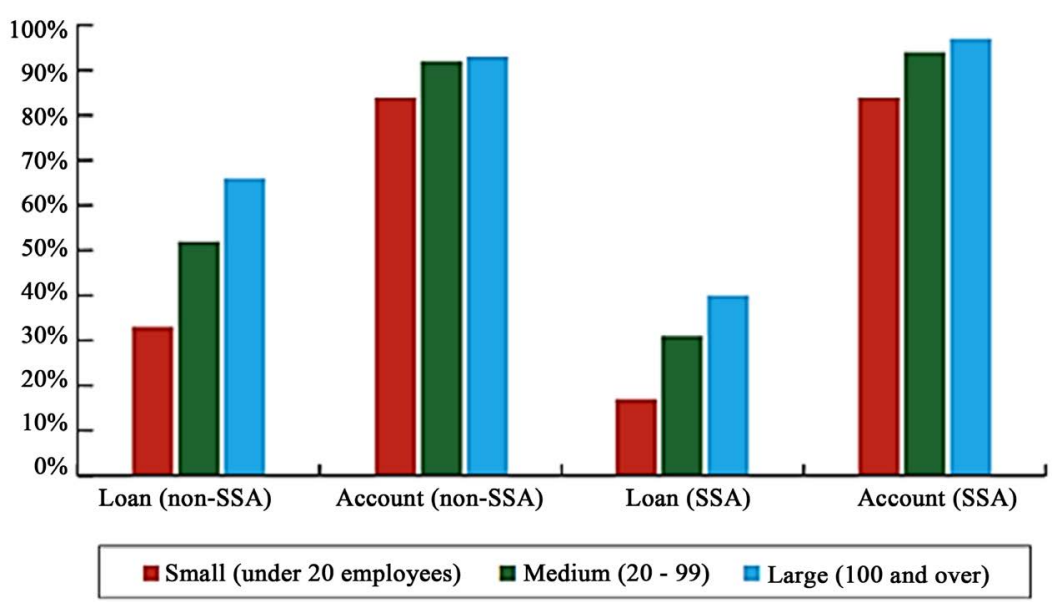

Figure 1. Use of formal account and loan services across firm size groups, an international comparison.

bility that a small firm lists financing as a major obstacle (as opposed to moderate, minor or no obstacle) is $39 \%$ compared to $36 \%$ for medium-size firms and $32 \%$ for large firms. The higher financing obstacles that small firms report match not only anecdotal evidence from both developed and developing countries, they also confirm theory's predictions.

It has also been identified by the Association of Ghana Industries (AGI), an umbrella of industries in Ghana which includes SMEs, that inadequate access to credit is the leading factor restricting the growth of small businesses in Ghana [21]. [22]-[24] also attributes the limited access to credit which they consider as a major hindrance to SMEs growth to the fact that most of the economies are poorly developed in the banking sectors.

In a world with fixed transaction costs and information asymmetries, small firms with demand for smaller loans face higher transaction costs and higher risk premiums since they are typically more opaque and have less collateral to offer. The research by [15] shows that access to finance was not an issue to SMEs in most European countries, but rather finding customer, in other words, finding market was the bigger issue. Figure 2 below from their research ranks access to finance as the third obstacle faced by the SMEs in the Euro zone.

When it comes to SMEs who have applied and been successful in securing loans from the bank, SMEs in the Euro zones stands the better chance than their counterparts in African countries. The survey indicated a whooping over 66\% of SMEs been successful in applying and getting loans from the banks [15]. Figure 3 below from the research by the Central European Bank gives the statistics on the success and rejection rate of SMEs application for bank loans.

Comparing the findings of CEB to that of Becks and Cull on the obstacles to SMEs development in both regions, the question is why the story is different for SMEs access and use of bank loans in African countries?

There is every indication that there is a financial gap in SMEs access to formal financing, but more prominent in sub-Saharan Africa countries.

Bank loans and trade credits, still considers as the cheapest and major sources of external finance to SMEs [25] [26], as a result, any restrictions on bank lending activities and trade credit facilities to SMEs, affects their growth, as presented by [27] [28] that growth in bank loans and trade credits stimulate firms investments which in the long run triggers growth.

Research by [29] revealed a credit gap of well over $\$ 2$ trillion for SMEs in emerging markets. The gap for formal SMEs alone was close to $\$ 1$ trillion. The estimated credit gap for formal and informal MSMEs worldwide has been revised upwards to $\$ 3.2$ to 3.9 trillion globally, of which $\$ 2.1$ to 2.6 trillion is in emerging markets IFC Enterprise Finance Gap Database (2011). This has been attributed to a number of factors including limited access to capital markets, financial institutions and poor managerial practices.

\subsection{Sources of SMEs Informal Financing}

\subsubsection{Family and Friends}

Financing businesses from family and friends have been considered as very significant source for providing seed 


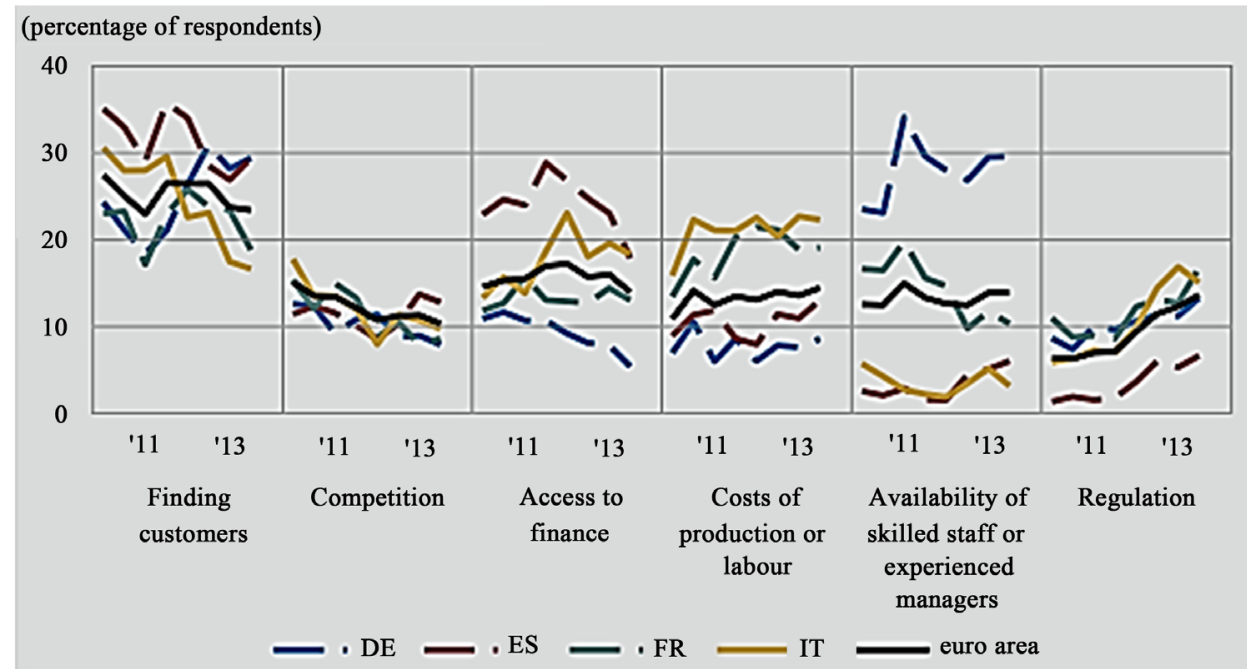

Base: All SMEs. Figures refer to round three (March-September 2010) to round ten (October 2013-March 2014) of the survey.

Figure 2. SMEs challenges in European Commission (EC).

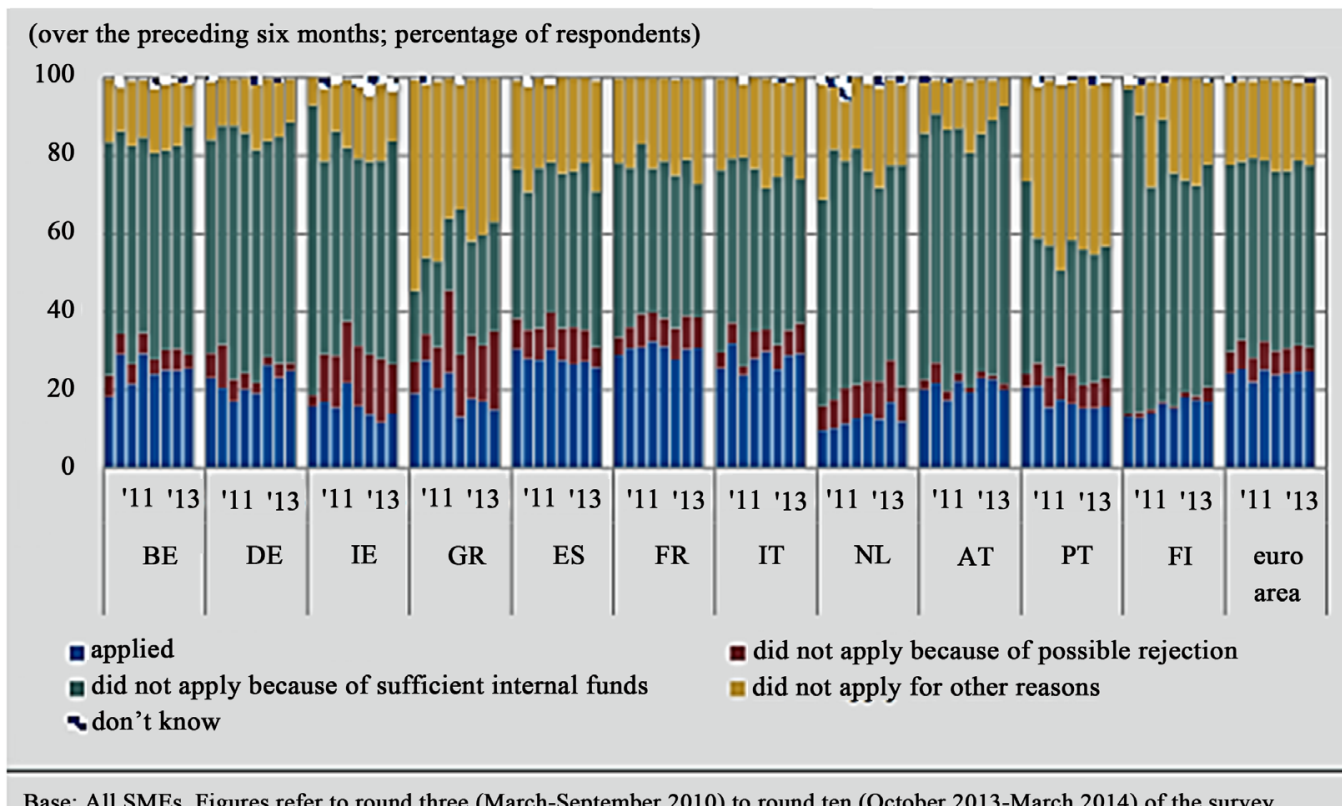

Figure 3. Survey on the access to finance of small and medium-sized enterprises in the Euro Area/April 2004.

capital for most start-ups and expansion, as it remains the popular choice for the poor entrepreneurs in developing countries [30]. In their quest to narrow the financing gap in SMEs finance, as recorded by MasterCard, that an estimated \$5 trillion financing gap exist globally in the business financing market. SMEs in developing countries rely heavily on family and friend and micro financial institutions to finance their ventures [31].

In family financing [32], posited that, there is no legal liability between the borrower and the lender, but in place is a social indebtedness, since legal actions are not mostly initiated in the event of default and breach of contract, but rather social exclusion and dis-communication exist. As a result, a family source of finance is based on trust, relations, character perception, which normally leads to high risk and default rate. Whiles the risk associated, remains in the entrepreneur's social sphere as it exposes the social relations to negative feedback effect. 


\subsubsection{Rotating Savings and Credit Associations (ROSCAs)}

This source of SMEs financing is peculiar to Ghana and some parts of African countries, which is known in the local parlance as "susu" in Ghana [33]. This type of financing was made popular by PAMSCAD in the early part of 1980s in Ghana, during the ERP era. The principles underpinning this type of financing is trust, which offsets the risk associated with other forms of finance for the union is based on cronyism and mutual interest [34]. Contributions are made on daily bases to the leader of the group, and depending on agreed duration, the sum of the contribution is given to one member on rotational bases till each member receives his turn. They may not be interest on the amount received.

\subsubsection{Inheritance}

Inheritance is one of the sources of capital for starting a new business or expanding an existing one. This is the system whereby rights, obligations, titles, debts and property are passed on when some dies. It has contributed significantly in human societies over the years. There has been dynamism in the rules of inheritance over the years and are distinct from one society to another. There exist two forms of inheritance, namely matrilineal and patrilineal. [35] posit that people whose tribal customs are matrilineal define their lineages through their female bloodlines only: their mothers and maternal cousins, aunts, uncles, grandparents, and so on are their blood kin; but their fathers and paternal cousins, aunts, uncles, grandparents, and so on are not. People whose tribal customs are patrilineal analogously define blood kinship as flowing through their paternal, but not maternal bloodlines. Under matrilineal lineage norms, a man's children are thus not his blood kin, and his heir should he die intestate (without a legal will) is his sister's son, his nearest blood relative in the next generation whiles under patrilineal norms, his estate devolves to his children, who are considered his blood kin [35]. However, [35] further stated that, under both traditional norms, widows have no inheritance rights and are often left with no assets because of a traditional presumption that assets acquired during marriage belong to the husband. Rather than relying on their husbands' estates, they must depend on their lineages' social safety nets. Ghana, until 1985, intestate inheritances were determined by traditional custom, and this depended on how one's extended family was defined [36]. On June 141985 the Intestate Succession Law (PNDCL 111) was promulgated by the Government of Ghana [36] [37]. According to [35], the 1985 Intestate Succession (PNDC) Law 111 was enacted to alter perceived adverse effects of these traditional norms, especially on widows with husbands of matrilineal lineage. The main innovation brought by the Law was the specific protection granted to members of the nuclear family (as opposed to the extended family) in the distribution of the man's self-acquired property on his death intestate [37]. The Law states that, after the house and household chattels are devolved entirely to the spouse and children, the residue of a man's intestate property has to be distributed as follows: nine-sixteenth to children, three-sixteenth to surviving spouse, one eighth to surviving parents and the remaining one-eighth, in the case of the matrilineal Akan [37]. The Law applies to all property which a deceased could have but did not dispose of through will [38].

\subsubsection{Business Angels}

Business angels are an important source of finance for smaller businesses [39]. Business angels are individuals who offer risk capital to unlisted firms in which they have no family-related connections [40]. Today it is widely acknowledged that business angels play a vital role in the development and growth of new ventures, in terms of both the financial capital they invest as well as offering their business skills and personal networks they have acquired throughout their professional lives [41] [42]. According to [39], business angels invest with the primary motive of making a financial return, but non-financial motives also play an important part, for example, business angels often enjoy being involved in growing a business and may also harbor altruistic motives, such as wishing to help budding entrepreneurs or wanting to make a contribution to the local economy. The amount of capital that angels provide is estimated to be eleven times that provided by venture capitalists [43] [44]. Data collected by [45] from different surveys conducted between 2001 and 2003 showed that between 140,000 and more than 260,000 angels injected investments between $\$ 12.7$ and $\$ 36$ billion into between 50,000 to 57,000 ventures each year. For instance, a study by [46] in Germany estimated the total capital assets for each business angel in the country at $€ 2.5$ million to $€ 5$ million distributed across a portfolio of between 1 and 5 firms, all start-ups.

\subsection{Criteria for Accessing Finance from the Informal Financial Systems}

Informal financial institutions consider several factors before granting financial assistance to SMEs so as to re- 
duce the rate of default. Factors such as credit worthiness, trust, reputation, familiarity, relation, performance and firm location, among other factors have been considered as a major determinants of SMEs access to informal credit [47] [48]. Although, it is established that many factors affect SMEs access to credit from the informal sector, however based on this study the researchers focused on trust, relation (family affiliation), religious affiliation and reputation in developing the model. These factors are arguably the most dominant determinants in the specific region where the study was undertaken.

\subsubsection{Trust}

Informal finance is considered as a source of trust capital, hence the borrowers must be trust worthy before granted their demand. To avert the risk associated with SMEs financing, the background of the borrowers are checked, and linked with certain monuments and personalities, thus making informal financing more secured [32].

This is because; lenders in informal financial sectors can reduce the operational cost of lending through access to superior information and reduction in the moral hazard of the borrowers, which is all base on trust [49].

For the problem of meeting the "trust" as a requirement, most SMEs avoid family finance, though it may be relatively cheaper than other sources [30]. Trust between SME owners and lenders decreases information asymmetry and consequently increases access to credit as well as the amount of credit granted to them [50]. Disclosing the information required by financial institutions, SMEs can benefit by increasing the probability of acceptance, increasing the amount of credit made available to them, and decreasing the amount of collateral/guarantees required [51] [52]. A recent study by [53] established a positive association between the amount of credit and the reduction in information asymmetry as well as examined the economic impact of reduced information asymmetry and found that the amount of short-term credit obtained increases by $12 \%$ if information asymmetry reduces by one notch. This indicates an inverse relationship between the level of information asymmetry and the level of trust between providers of credit and borrowers of credit. A reduction in information asymmetry increases the trust between financial institutions and seekers of credit which consequently increases the amount of credit granted SMEs and all loan seekers in general [54]. In the light of this argument, the first hypothesis is formulated as follows:

H1: Trusting the owners/managers of SMEs increases the chances of accessing financial assistance from the informal financial systems.

\subsubsection{Relation}

The ability to obtain credit or otherwise from any financial institution (formal or informal is also dependent on societal relationship between a lender and a borrower. The importance of networks in society cannot be overemphasized as a result of its role in developing the private sector in contributing to gross domestic product (GDP), employment creation, and raising income levels through its spill-over effects as well as access to credit [55]. Social networks seem to play a crucial role in the world of entrepreneurship. Startup firms are generally endowed with little legitimacy and few of the resources needed to acquire the information, capital, and skills for survival and growth [56]-[60]. To overcome these constraints, entrepreneurs often draw upon their "social capital" [61]-[63] confirm the importance of social relations in the decisions to grant credit in Italy and China. According to these authors, the banks that are geographically close to their customers present limited credit risk, as they are more efficient in their control on borrowers and hold an informational advantage over those that are located at farther distances. Banks nowadays have adopted the group lending methodology to provide credit to SMEs and the poor at large [64]. The whole group is liable if one or more group members default. Thus, joint liability provides an insurance against individual risks. Even if an individual project fails and some of the borrowers are unable to repay, the group as a whole might still be able to do so. In this sense joint liability serves as a substitute for collateral [65]. According to [66], successful programs like Grameen Bank and Bancosol have shown high repayment rates, as high as 90 to 95 per cent of all loans made to groups. Screening, monitoring and enforcement activities are the three main activities performed by members of the group [66]. Most groups consist of blood relations and friends who serve as guarantee to each other to ensure repayment of loans granted to them by banks as well as guarantee for more access to credit in future. The question is "can social ties in the form of group lending also guarantee access to credit from the informal financial sector?” This forms the foundation of our second hypothesis:

H2: Owners/Managers with blood relation (family Affiliation) with the lender increases the chances of getting financial assistance from the informal systems. 


\subsubsection{Reputation}

Traditionally, credit and reputation have been closely linked [67] [68], since the sixteenth century, whiles [69] argues that, reputation was virtually synonymous with good credit. Credit could be won or lost on reputation, but the causation ran both ways, as ability to secure credit affected one's non-monetary reputation as well. Lending money was a mark of honor, which also signaled the honor and acceptance of the borrower. Loss of credit meant loss of honor. Connections between social status, honor, moral worth, and credit, Mann notes, continued even as society grew more commercial and transactional, with credit available to a wider range of people [69]. Before the nineteenth century, financial reputations were generally mediated by the local community, where people were well known and where knowledge of their character, behavior, and business practices circulated freely. Reputation in the nineteenth-century sense is best defined as the public knowledge or understanding of character - what was generally believed about a person [70]. However, reputation and character were not exactly the same thing. Character spoke of the essential moral makeup of a person. Reputation, on the other hand, might be mere popular belief-delusional and unstable and thus the opposite of solid character [70]. False representations and popular delusions could set a trap for the unwary investor, who listened to the foolishness of the crowd without inquiring more deeply into the essence of the man. A good reputation might hide an evil character, while virtuous character could redeem a suspect reputation [70]. Borrowers rely on building positive reputations for repayment of debts in order to secure access to future credit. [71] posits that an increasing number of finance institutions provide credit to the poor on the basis of "social collateral", through which borrowers' reputation or the social networks to which they belong, take the place of traditional physical or financial collateral. According to [72], almost one-third of families who had been denied credit in the past five years in United States of America had not gotten the desired credit because of their potentially spotty record and another 13.2 percent were denied credit because they had no credit history. Therefore, reputation of a borrower is a catalyst to gaining access to credit from lenders. This supports our third hypothesis which states:

H3: Owners/Managers with high reputation have the greater chances of getting financial assistance from the informal financial system.

\subsubsection{Religious Affiliations}

Governments, institutions, policy makers and individuals throughout the world realizing the fundamental importance and benefits that Small and Medium enterprises offer [73] have developed several innovative financial products to make credit accessible, reliable and affordable to small businesses. For instance, the UK coalition government, from day one of their tenure, has championed small and medium business as central to economic recovery, expending exhaustive amounts of time and money to persuade banks to increase lending to SME's and start-ups. These efforts included the Business Growth Fund, the Enterprise Finance Guarantee, and lately, the Funding for Lending Scheme [74]. [75] reveals some of the governmental agencies in Ghana which provide support for SMEs include National Board for Small-Scale Industries (NBSSI), Business Assistance Fund, Ghana Investment Fund, GRATIS Foundation, Rural Enterprise Project (REP) and Microfinance and Small Loans Centre (MASLOC). The government of Ghana in 2014 established Youth Enterprise Support (YES) fund with \$2.7 million (10 million Ghana Cedis) seed capital toboost the creativity and entrepreneurial skills of young Ghanaians [76]. Amongst the institutions which are also spearheading the need for entrepreneurs and small businesses in general to acquire consistent and affordable credit are religious bodies. Does religious affiliation aids in accessing credit from financial institutions? This is an area worth exploring. Religiosity has been defined by [77], as "the degree to which specific beliefs in religious values and ideals are held and practiced by an individual". Religion is believed to be a binding force between worshippers and the Supreme Being as well as a group of people sharing the same faith [78]. Religious affiliation is associated with and guided by certain beliefs which includes arms giving, caring for one another and oneness [79], these principles and practices, when transferred to solving the financial needs of members (entrepreneurs), relief the financial burden from these member entrepreneurs [80], they further explained that in the context of business activities, religious commitment will determine the consistency of behavior exhibited by a person in running a business, such as business practices that give priority to ethics, honesty and trustworthy. One of the religious bodies which has stepped up its effort in helping the poor and small businesses gain access to credit is the "Church". Some Churches in many nations have established Credit Unions (CU) to grant reliable credit to its members as well as promote their welfare at large [81]. Nations with the most credit union activity include the U.S., India, Canada, South Korea, Japan, Mexico, Australia, Kenya, Ireland, Thailand, and Brazil [82]. The Credit Union Association, Ghana (CUAG), 
churches like Action Chapel, Assemblies of God, Church of Pentecost, Roman Catholic Church, Methodist Church, Presbyterian Church, Trinity Church, Seventh Day Adventists Church and Baptist Church have established Credit Unions throughout various parts of the country. According to [81], one reason the Church backs the credit union movement is that it helps to relieve people from the oppression of economic insecurity. This is supported by [83] stating that many churches look to getting involved in Credit Unions as a means of helping those who are financially excluded. According [83] further stated that many Credit Unions now give loans, without first needing to save, based on a person's ability to repay, by assessing income and expenditure from a budget, pay slips, and bank statements. Is it a guarantee for a member of a church to gain access to reliable and affordable credit from its credit union? This paper investigates this phenomenon and therefore establishes our fourth hypothesis:

H4: Owners/Managers who have religious affiliation with the lender have greater chances of getting financial support from the financial institutions of such religious bodies.

\section{Research Methodology}

A survey design was used to achieve the objective of this study. According to [84], the selection of an appropriate sampling method depends upon the aim of the study. Both qualitative and quantitative methods were employed in answering the research questions. Based on the nature of the study, a purposive sampling technique was employed for the study. The purposive method allows the researcher to actively select the most productive sample to answer the research questions [84]. The respondents were owners/managers of SMEs in the Ashanti Region. The participants for the study were chosen from the Ashanti Region. The Ashanti Region is one of the busiest and Regions in Ghana. The region is the second largest in terms of population and has majority of small and medium enterprises making it a well-befitting for this study. The primary data were gathered using questionnaires and interviews whereas the secondary data were mainly collected from available literature from renown works by researchers who are endowed with knowledge pertaining to the current subject under study. Two hundred questionnaires were sent, however, 185 representing $92.5 \%$ was used for the analysis. Researchers together with their assistants visited the various offices of the organisations. The purpose of the study was well explained to them and their consents were sought before the questionnaires or and the interviews were conducted. Those who cannot read the questionnaires were interviewed based on the questionnaires developed by the researchers. The questionnaire consisted of three sections. Section A of the questionnaire sought to gather demographic characteristics of the respondents. Section B of the questionnaire consistent 7 items which gathered data on the level of use or access of informal financial services by the SMEs. Finally, in section C the participants responded to the requirements for accessing credit from the informal financial systems. The questionnaire was designed by the researchers and was tested using the cronbach's alpha to determine the internal consistency of the instrument. The alpha coefficients ranged from 0.745 to 0.865 .

The researchers used Statistical Package for Social Sciences (SPSS 22.0) in the analysis of the data. Firstly, the questionnaires were coded to eases easy identification. The researchers screened the data and discarded questionnaires which were not appropriately filled. The items were then scored. Items on the five point-likert scale were scored 1, 2, 3, 4 and 5 for items with the response strongly disagree, disagree, neither agree nor disagree, agree and strongly agree respectively. Descriptive statistics, Stepwise Multiple Regressions were the statistical tools used in analyzing the data.

\section{Analysis and Findings}

Table 1 shows the details of the characteristics of the sample. It shows the distribution of gender, age, and marital status. There were 95 (51.4\%) males and 90 (48.6\%) females who responded to the questionnaires and the interviews. Majority of the respondents fall within the ages of 20 to 30 years, they were 69 representing 37.3\%. Single respondents were 96 representing (51.9\%) while 89 (48.1\%) were married.

Table 2 presents the level of use of SMEs financing in the informal systems. Concerning the family informal financial system, 10 (13\%) reported low level of use while 68 representing 87\% reported high level of use. Financing their businesses from friends, 5 (13.5\%) reported low level of use and 32 (86.5\%) reported high level of use. Furthermore, $83.3 \%$ and $16.7 \%$ reported low level of use and high level of use respectively with regard to religious affiliation. Again, with regard to political affiliation, 13 (56.5\%) recorded low level of use whereas, 10 (43.5\%) reported high level of use. About 54\% financed their business outside or in combination of these informal financial services (family, friends, religious and political affiliations). 
Table 1. Characteristics of the respondents.

\begin{tabular}{ccc}
\hline Variables & & N (\%) \\
\hline Gender: & Male & $95(51.4)$ \\
& Female & $90(48.6)$ \\
Total & & $\mathbf{1 8 5}(\mathbf{1 0 0})$ \\
Age: & $20-30$ & $69(37.3)$ \\
& $31-40$ & $46(24.9)$ \\
& $41-50$ & $27(14.6)$ \\
Total & 50 or above & $43(23.2)$ \\
Marital Status: & & $\mathbf{1 8 5}(\mathbf{1 0 0 )})$ \\
& Single & $96(51.9)$ \\
Total & Married & $89(48.1)$ \\
\hline
\end{tabular}

Source: Field Data.

Table 2. The level of use of informal financial system.

\begin{tabular}{|c|c|c|c|}
\hline Variables & Low Level of Use N (\%) & High Level of Use N (\%) & Total N (\%) \\
\hline Family & $10(13)$ & $68(87)$ & $78(100)$ \\
\hline Friends & $5(13.5)$ & 32 (86.5) & 37 (100) \\
\hline Religious Affiliation & $5(83.3)$ & $1(16.7)$ & $6(100)$ \\
\hline Political Affiliation & $13(56.5)$ & $10(43.5)$ & $23(100)$ \\
\hline Others & $19(46.3)$ & $22(53.7)$ & $41(100)$ \\
\hline Total & $52(28.1)$ & 133 (71.9) & $185(100)$ \\
\hline
\end{tabular}

Source: Field Data.

Table 3 shows the requirements for accessing financial assistant in the informal financial system. The interview conducted shows that, 167 (90.3\%) confirmed that one needs to be a family member in order to access financial assistance from the family financial system while 18 (9.7\%) reported "no" to this assertion. 170 (91.1\%) and 160 (86.5\%) confirms that, entrepreneurs need to be trustworthy and live exemplary life respectively in order to access financial assistance from the informal financial system. Furthermore, 56.2\% reported that, being affiliated to a religious body increases the chances of access of finances especially from the ruling party.

Figure 4 represents the level of access of finances from the informal financial systems (Family, Religious and Political Affiliations, Friends and others). The figures show that $29.9 \%$ of the respondents are likely to get access of finances from family members. $11.5 \%$ are likely to access finances from religious affiliation, $16.2 \%$ from the political affiliation, $28 \%$ from friends and $19.7 \%$ from other sources outside family, friends, religious and political affiliations.

Table 4 shows the summary of the stepwise multiple regression. The model 1 shows a correlation coefficient of $0.521, R^{2}$ of 0.193 and Adjusted $R^{2}$ of 0.172 . When the second independent variable was added to the model, correlation increased to $0.447, R^{2}$ was 0.200 and adjusted $R^{2}$ of 0.96 . When the third independent variable was added to the model correlation increased to $0.54, R^{2}$ increased to 0.292 and the Adjusted $R^{2}$ increased to 0.284 . Finally the model improved when the last independent variable was included in the model, showing overall correlation coefficient of 0.556 , coefficient of determination increasing to 0.309 and an Adjusted $R^{2}$ to 0.297 . The model predicts that about $31 \%$ of the total variability in the dependent variable is explained by the independent variables. The calculated Adjusted $R^{2}$ of 0.297 , indicates that $29.7 \%$ of the impact on access of finance in the informal financial systems is explained by the model and about $70.3 \%$ provides explanations outside this model.

Table 5 presents the results of coefficients of the predictors of access of finance in the informal financial sys- 


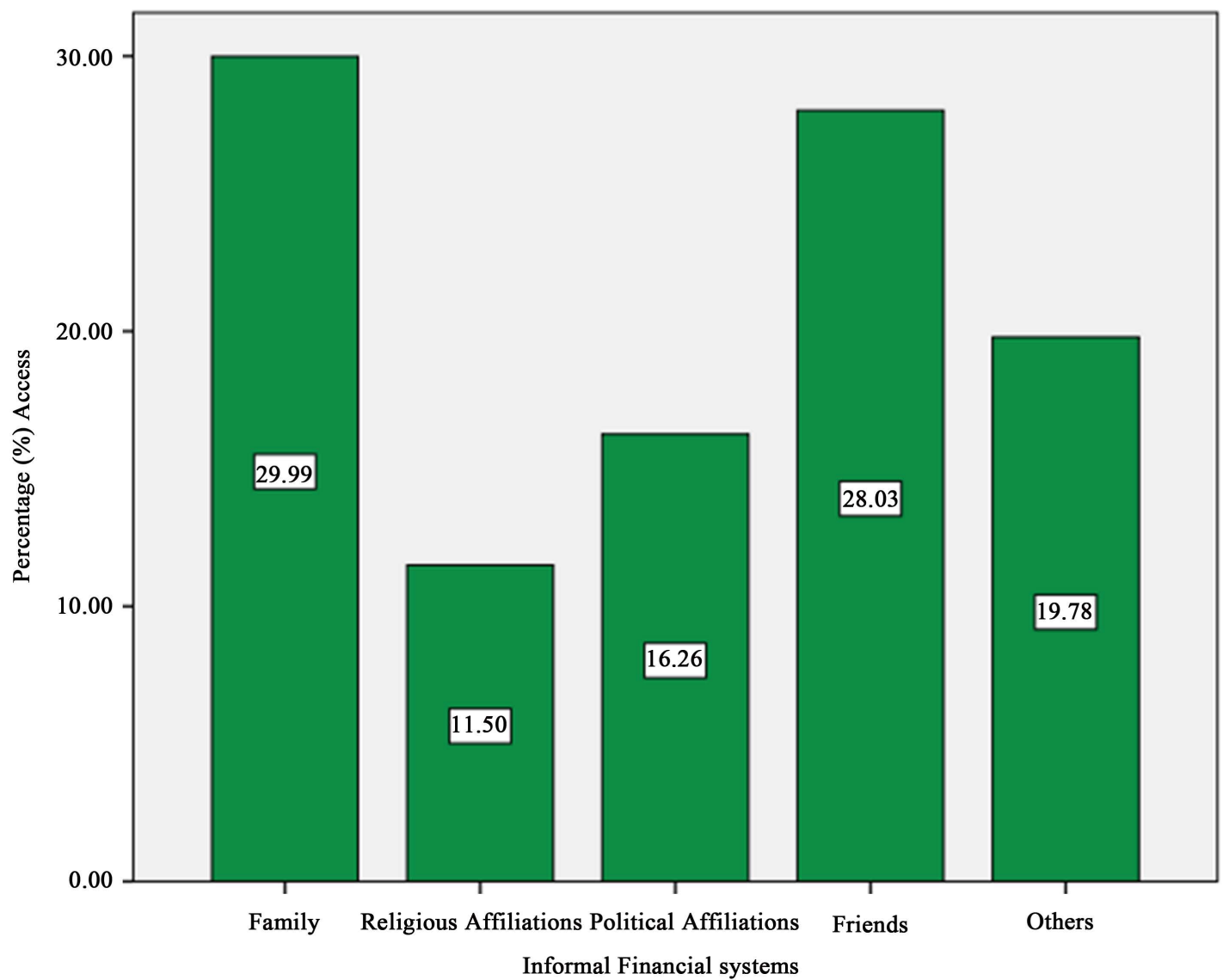

Figure 4. Informal financial access.

Table 3. Requirements for accessing finances in the informal sector.

\begin{tabular}{cccc}
\hline & No & Yes & Total \\
\hline Requirements & $\mathrm{N}(\%)$ & $\mathrm{N}(\%)$ & $\mathrm{N}(\%)$ \\
I have to be a family member & $18(9.7)$ & $167(90.3)$ & $185(100)$ \\
I have to be trustworthy & $15(8.1)$ & $160(86.5)$ & $185(100)$ \\
I have to live an exemplary life & $25(13.5)$ & $104(56.2)$ & $185(100)$ \\
I have to be an affiliate to a Religious Affiliation & $81(43.8)$ & & $100)$ \\
\hline
\end{tabular}

Source: Field Data.

Table 4. Model summary.

\begin{tabular}{ccccc}
\hline Model & R & R-Square & Adjusted R Square & Std. Error of Estimation \\
\hline 1 & 0.521 & 0.193 & 0.172 & 7.42632 \\
2 & $0.447^{\mathrm{b}}$ & 0.200 & 0.196 & 7.09022 \\
3 & $0.540^{\mathrm{c}}$ & 0.292 & 0.284 & 6.69039 \\
4 & $0.556^{\mathrm{d}}$ & 0.309 & 0.297 & 6.62148 \\
\hline
\end{tabular}

a. Predictors (Constant), Trust; b. Predictors (Constant), Trust, Reputation; c. Predictors (Constant), Trust, Reputation, Family Affiliation; d. Predictors (Constant), Trust, Reputation, Family Affiliation, Religious Affiliation. 
Table 5. Coefficients.

\begin{tabular}{|c|c|c|c|c|c|c|c|c|}
\hline \multirow{3}{*}{\multicolumn{2}{|c|}{ Model }} & \multicolumn{5}{|c|}{ Stadardized } & & \\
\hline & & \multicolumn{2}{|c|}{ Unstandardized Coefficients } & \multicolumn{2}{|c|}{ Coefficients } & \multirow[b]{2}{*}{ Sig. } & \multicolumn{2}{|c|}{ Collinearity Statistics } \\
\hline & & B & Std. Error & Beta & $t$ & & Tolerance & VIF \\
\hline \multirow[t]{2}{*}{1} & (Constant) & 19.345 & 1.843 & & 10.422 & 0.000 & & \\
\hline & Trust & 4.343 & 0.441 & 0.682 & 8.512 & 0.000 & 1.000 & 1.000 \\
\hline \multirow[t]{3}{*}{2} & (Constant) & 14.99 & 1.572 & & 9.534 & 0.000 & & \\
\hline & Trust & 4.012 & 0.401 & 0.542 & 8.321 & 0.000 & 1.000 & 1.000 \\
\hline & Reputation & 2.537 & 0.375 & 0.447 & 6.766 & 0.000 & 0.981 & 1.019 \\
\hline \multirow[t]{4}{*}{3} & (Constant) & 7.224 & 2.183 & & 3.309 & 0.001 & & \\
\hline & Trust & 3.651 & 0.884 & 0.453 & 8.336 & 0.000 & 0.981 & 1.019 \\
\hline & Reputation & 2.297 & 0.357 & 0.405 & 6.431 & 0.000 & 0.981 & 1.019 \\
\hline & Family Affiliation & 1.988 & 0.41 & 0.306 & 4.85 & 0.000 & 0.981 & 1.019 \\
\hline \multirow[t]{5}{*}{4} & (Constant) & 5.562 & 2.301 & & 2.417 & 0.170 & & \\
\hline & Trust & 3.46 & 2.101 & 0.368 & 6.311 & 0.000 & 0.973 & 1.032 \\
\hline & Reputation & 2.221 & 0.356 & 0.392 & 6.245 & 0.000 & 0.971 & 1.031 \\
\hline & Family Affiliation & 2.032 & 0.406 & 0.312 & 5.000 & 0.000 & 0.978 & 1.022 \\
\hline & Religious Affiliation & 0.621 & 0.294 & 0.131 & 2.114 & 0.360 & 0.988 & 1.012 \\
\hline
\end{tabular}

$* p<0.05$. Note: VIF = Variance Inflation Factor, 1 = Predictors: (Constant) Trust 2 = Predictors: (Constant) Trust, Reputation $3=$ Predictors: (Constant) Trust, Reputation, Family Affiliation. 4 = Predictors: (Constant) Trust, Reputation, Family Affiliation, Religious Affiliation. Dependent variable: access of financial support from the informal systems.

tems. The collinearity statistics show no evidence of multicollinearity as all variance inflation factor is below the cutoff of 10.0 [85] [86]. The stepwise multiple regression was run to find out the impact of each predictor variable on the criterion variable. The model indicated that trust significantly predicted financial support from the informal financial system $\left(\beta=0.521, t(184)=8.512, p=0.000, R^{2}=0.193\right)$. The model shows that, reputation was a significant predictor of access of finance in the informal financial system $(\beta=0.447, t(183)=6.766, p=0.000$, $R^{2}=0.200$ ). Religious affiliation was the least significant predictor of financial access in the informal financial system at $\left(\beta=0.131, t=181, p=0.000, R^{2}=0.309\right)$. These results indicated that, all the alternative hypotheses in the study are supported. Indicating that, Trust, Reputation, family affiliations (relations), and Religious affiliations are significant predictors of financial access in the informal financial system.

\section{Discussions and Conclusion}

There is ample evidence that SMEs stand the chance of getting financial assistance from the informal financial systems as an alternative source source of finance, provided they are able to meet the requirement, which is much easier than those required by the formal financial systems, as indicated in the research findings that, a greater percentage of the SMEs surveyed relies heavily on the informal financial system (refer to Section 4). If is well managed, informal finance source will become the panacea for SMEs financing in developing countries as proposed by [6].

The problem with the system is the irregular nature of the requirements which gives more determinant factor to the lender whiles the borrower has to build up his/her reputation and trust, but areas such as family relation and religious affiliation cannot be altered easily.

On the other hand, owner managers who are able to meet the requirements of the informal financial system, are advice to capitalized on the cheaper interest rate to raise more capital for expansion. Family members and religious bodies with good financial standing should be encouraged to support owner managers within their do- 
main to improve business performance.

On the concerns by lenders on the issue of high rate of defaulting, more checks and balances must be put in place. Also the government should provide credit guarantee schemes and favorable legal framework to cushion the lenders. This falls in line with relevant literatures reviewed in section two of this study [12].

\section{References}

[1] (1992) Nation-Wide Survey. Gemini Technical Report No. 46, Development Alternatives Inc., Washington DC.

[2] Daniels, L. (1994) Changes in the Small-Scale Enterprise Sector from 1991 to 1993: Results of a Second Nation Wide Survey in Zimbabwe. GEMINI Working Paper No. 71, GEMINI, Bethesda.

[3] Donald, and T. Biggs, T. (1996) Industrialization and the Small Firm. International Center for Economic Growth, San Francisco.

[4] Davidsson, P. and Henrekson, M. (2002) Determinants of the Prevalence of Start-Ups and High-Growth Firms. Small Business Economics, 19, 81-104. http://dx.doi.org/10.1023/A:1016264116508

[5] Thurik, A.R. and Wennekers, A.R.M. (2004) Entrepreneurship, Small Business and Economic Growth. Journal of Small Business and Enterprise Development, 11, 140-149. http://dx.doi.org/10.1108/14626000410519173

[6] Beck, T., Demirguc-Kunt, A. and Laeven, L. (2005) Small and Medium-Size Enterprises: Overcoming Growth Constraint. JEL Classifications, L11, O1-O4.

[7] Ayyagari, A., Demirgu-Kunt, M. and Maksimovic, V. (2011) Small vs. Young Firms across the World: Contibution to Employment, Job Creation, and Growth Policy Research Working Paper 5631, Washington DC. http://dx.doi.org/10.1596/1813-9450-5631

[8] Beck, T. and Robert, C. (2014) Small- and Medium-Sized Enterprise Finance in Africa. Africa Growth Initiatives, Working Paper.

[9] OECD (2010) SMEs and Entrepreneurship: Lessons from the Global Crisis and the Way forward to Job Creation and Growth. Innovative SMEs and Entrepreneurship for Job Creation and Growth BOLOGNA.

[10] ILO (2008) Skills for Improved Productivity, Employment Growth and Development International Labour Conference. International Labour Office, Geneva.

[11] NESTA (2007) Innovation in Response to Social Challenges.

[12] Ayyagari, M., Demirguc-Kunt, A. and Maksimovic, V. (2008) How Important Are Financing Constraints? The Role of Finance in the Business Environment. Geneva.

[13] Dalberg (2011) Report on Support to SMEs in Developing Countries through Financial Intermediaries.

[14] IFC (2012) Scaling Up Access to Finance for Agricultural SMEs: Policy Review and Recommendations and Innovative Agricultural SME Finance Models, 12-13.

[15] European Central Bank (2014) Survey on the Access to Finance of Small and Medium-Sized Enterprises in the Euro Area. 1831-9998 (Online) QB-AP-14-001-EN-N.

[16] Beck, T., Asli, D.-K. and Levine, R. (2005) SMEs, Growth, and Poverty: Cross-Country Evidence. World Bank Mimeo. http://dx.doi.org/10.3386/w11224

[17] Schiffer, M. and Weder, B. (2001) Firm Size and the Business Environment: Worldwide Survey Results. Discussion Paper 43, International Finance Corporation, Washington DC.

[18] Calice, P., Chando, V. and Sekioua, S. (2012) Bank Financing to Small and Medium Enterprises in East Africa: Findings of a Survey in Kenya, Uganda, Tanzania and Zambia. African Development Bank, Abidjan.

[19] Levine, R., Loayza, N. and Beck, T. (2000) Financial Intermediation and Growth: Causality and Causes. Journal of Monetary Economics, 46, 31-77. http://dx.doi.org/10.1016/S0304-3932(00)00017-9

[20] Beck, T., Demirgüç-Kunt, A. and Peria, M.S.M. (2011) Banking Financing for SMEs: Evidence across Countries and Bank Ownership Types. Journal of Financial Services Research, 39, 35-54. http://dx.doi.org/10.1007/s10693-010-0085-4

[21] AGI (2011) Business Barometer Report Is a Periodic Opinion Survey about What Chief Executives Make of the Business Environment.

[22] EBRD (2004) SME Finance in the Early Transition Countries: The EBR’s Experience. European Bank for Reconstruction and Development, London.

[23] Hossain, N. (1998) Constraints to SME Development in Bangladesh. Paper Prepared for Job Opportunities and Business Support (Jobs) Program, Mimeo. 
[24] PECC (2003) Financing Small and Medium Enterprises Challenges and Options. Issues@PECC, Pacific Economic Cooperation Council.

[25] Petersen, M. and Rajan, R. (1994) The Benefits of Lending Relationships: Evidence from Small Business Data. Journal of Finance, 49, 3-37. http://dx.doi.org/10.1111/j.1540-6261.1994.tb04418.x

[26] Petersen, M. and Rajan, R. (1995) The Effect of Credit Market Competition on Firm-Creditor Relationships. Quarterly Journal of Economics, 110, 407-443. http://dx.doi.org/10.2307/2118445

[27] Greenwood, J. and Jovanovic, B. (1990) Financial Development, Growth, and the Distribution of Income. Journal of Political Economy, 98, 1076-1107. http://dx.doi.org/10.1086/261720

[28] Love, I. and Mylenko, N. (2004) Credit Reporting and Financing Constraints. Mimeo, World Bank, Washington DC.

[29] International Finance Corporation (2011) SMEs Finance Policy Guide. IFC, Washington DC.

[30] Collins, D., Morduch, J., Rutherford, S. and Ruthven, O. (2010) Portfolios of the Poor. Princeton University Press, Princeton.

[31] European Commission (2011) Small and Medium-Sized Enterprises (SMEs), SME Definition.

[32] Lee, S. and Petra, P. (2012) Financing from Family and Friends. Stern School of Business, New York University, New York.

[33] Steel, W.F., Aryeetey, E., Hettige, H. and Nissanke, M. (1997) Informal Financial Markets under Liberalization in Four Africa Countries. World Development, 25, 817-830. http://dx.doi.org/10.1016/S0305-750X(96)00133-7

[34] Nissanke, M. and Aryeetey, E. (2006) Institutional Analysis of Financial Market Fragmentation in Sub-Saharan Africa. A Risk-Cost Configuration Approach. Research Paper No. 2006/87.

[35] Kutsoati, E. and Morck, R. (2012) Family Ties, Inheritance Rights, and Successful Poverty Alleviation: Evidence from Ghana. NBER Working Paper No. 18080. http://dx.doi.org/10.2139/ssrn.2020542

[36] Gedzi, S.V. (2014) PNDC Law 111 in Ghana and International Human Rights Laws. Global Journal of Politics and Law Research, 2, 15-26.

[37] La Ferrara, E. and Milazzo, A. (2014) Customary Norms, Inheritance, and Human Capital: Evidence from a Reform of the Matrilineal System in Ghana.

[38] Woodman, G.R. (1985) Ghana Reforms the Law of Intestate Succession. Journal of African Law, 29, 118-128. http://dx.doi.org/10.1017/S002185530000663X

[39] Atrill, P. (2009) Being an Angel. Relevant to ACCA Qualification Papers F9 and P4.

[40] Politis, D. (2008) Business Angels and Value Added: What Do We Know and Where Do We Go? Venture Capital, 10, 127-147. http://dx.doi.org/10.1080/13691060801946147

[41] Mason, C.M. (2006) Informal Sources of Venture Finance. In: Parker, S., Ed., The Lifecycle of Entrepreneurial Ventures, Springer, Berlin, 259-299. http://dx.doi.org/10.1007/978-0-387-32313-8_10

[42] Kelly, P. (2007) Business Angel Research: The Road Travelled and the Journey Ahead. In: Landstr, H., Ed., Handbook of Research on Venture Capital, Edward Elgar, Cheltenham, 315-331. http://dx.doi.org/10.4337/9781847208781.00021

[43] Morrissette, S.G. (2007) A Profile of Angel Investors. Journal of Private Equity, 10, 52-66. http://dx.doi.org/10.3905/jpe.2007.686430

[44] Abdulsaleh, A.M. and Worthington, A.C. (2013) Small and Medium-Sized Enterprises Financing: A Review of Literature. International Journal of Business and Management, 8.

[45] Shane, S. (2012) The Importance of Angel Investing in Financing the Growth of Entrepreneurial Ventures. Quarterly Journal of Finance, 2, 901-942. http://dx.doi.org/10.1142/S2010139212500097

[46] Stedler, H. and Peters, H.H. (2003) Business Angels in Germany: An Empirical Study. Venture Capital, 5, $269-276$. http://dx.doi.org/10.1080/1369106032000126596

[47] Nguyen, N. and Luu, N.T.H. (2013) Determinants of Financing Pattern and Access to Formal-Informal Credit: The Case of Small and Medium Sized Enterprises in Viet Nam. Journal of Management Research, 5, 240-259. http://dx.doi.org/10.5296/jmr.v5i2.3266

[48] Safavian, M. and Wimpey, J. (2007) When Do Enterprises Prefer Informal Credit? World Bank Policy Research Working Paper No. 4435, Geneva.

[49] Stiglitz, J. (1990) Peer Monitoring and Credit Markets. The World Bank Economic Review, 4, 351-366. http://dx.doi.org/10.1093/wber/4.3.351

[50] Lehmann, E. and Neuberger, D. (2001) Do Lending Relationships Matter? Evidence from Bank Survey Data in Germany. Journal of Economic Behavior and Organization, 45, 339-359. 
http://dx.doi.org/10.1016/S0167-2681(01)00151-2

[51] Binks, M. and Ennew, C. (1996) The Impact of Service Quality and Service Characteristics on Customer Retention: Small Business and Their Banks in The UK. British Journal of Management, 7, 219-230. http://dx.doi.org/10.1111/j.1467-8551.1996.tb00116.x

[52] Zecchini, S. and Ventura, M. (2009) The Impact of Public Guarantees on Credit to SMEs. Small Business Economics, 32, 191-206. http://dx.doi.org/10.1007/s11187-007-9077-7

[53] Moro, A., Fink, M. and Maresch, D. (2015) Reduction in Information Asymmetry and Credit Access for Small and Medium-Sized Enterprises. Journal of Financial Research, 38, 121-143. http://dx.doi.org/10.1111/jfir.12054

[54] Moro, A. and Fink, M. (2013) Loan Managers’ Trust and Credit Access for SMEs. Journal of Banking \& Finance, 37, 927-936. http://dx.doi.org/10.1016/j.jbankfin.2012.10.023

[55] Peprah, J. (2011) Sustainable Entrepreneurship: The Role of Networking. 1-29.

[56] Stinchcombe, A.L. (1965) Social Structure and Organizations. In: March, J.P., Ed., Handbook of Organtzatlons, Rand McNally, Chicago, 142-193.

[57] Aldrich, H. and Auster, E.R. (1986) Even Dwarfs Started Small: Liabilities of Age and Size and Their Strategic Implications. In: Cummings, L.L. and Staw, B.M., Eds., Research in Organizational Behavior, CT JAI Press, Greenwich, 165-198.

[58] Freeman, J. (1997) Venture Capital as an Economy of Time. Unpublished Manuscript, Haas School of Business, University of California, Oakland.

[59] Karlan, D., Markus, M., Tanya, R. and Adam, S. (2009) Trust and Social Collateral. Quarterly Journal of Economics, 124, 1307-1361. http://dx.doi.org/10.1162/qjec.2009.124.3.1307

[60] Gana, M.R. (2013) Social Interactions and Access to Credit: The Case of Tunisian SMEs. Journal of Business Studies Quarterly, 4, 153-165.

[61] Wang, Y. (2008) Evaluation or Attention: How Do Social Ties Matter in Venture Financing ? MIT Sloan School of Management, 50 Memorial Drive, E52-511, Cambridge, MA, 1-47.

[62] Cotugno, M. and Stefanelli, V. (2011) Bank Size, Functional Distance and Loss Given Default Rate of Bank Loans. International Journal of Financial Research, 2, 31-44. http://dx.doi.org/10.5430/ijfr.v2n1p31

[63] Lei, C. (2013) The Development of the Relationship Lending Theory in China. Journal of Convergence Information Technology, 8, 1036-1043. http://dx.doi.org/10.4156/jcit.vol8.issue4.119

[64] Serageldin, I. and Grootaert, C. (2000) Defining Social Capital: An Integrating View. In: Dasgupta, P. and Serageldin, I., Eds., Social Capital: A Multifaceted Perspective, World Bank, Washington DC, 40-59.

[65] Abbink, K., Irlenbusch, B. and Renner, E. (2002) Group Size and Social Ties in Microfinance Institutions.

[66] Hermes, N., Lensink, R. and Mehrteab, H.T. (2006) Does the Group Leader Matter? The Impact of Monitoring Activities and Social Ties of Group Leaders on the Repayment Performance of Group Based Lending in Eritrea. African Development Review, 18, 72-97. http://dx.doi.org/10.1111/j.1467-8268.2006.00133.x

[67] Greif, A. (1989) Reputation Coalitions in Medieval Trade: Evidence on the Maghribi Traders. Journal of Economic History, 49, 857-882. http://dx.doi.org/10.1017/S0022050700009475

[68] Klein, D. (1997) Reputation: Studies in the Voluntary Elicitation of Good Conduct. University of Michigan Press, Ann Arbor.

[69] Mann, B. (2002) Republic of Debtors: Bankruptcy in the Age of American Independence. Harvard University Press, Cambridge.

[70] Lipartito, K. (2013) Mediating Reputation: Credit Reporting Systems in American History. Business History Review, 87, 655-677. http://dx.doi.org/10.1017/S0007680513001086

[71] Bastelaer, T.V. (2000) Imperfect Information, Social Capital and the Poor’s Access to Credit. 1-25.

[72] Weller, E.C. (2007) Access Denied: Low-Income and Minority Families Face More Credit Constraints and Higher Borrowing Costs. Center for American Progress, Washington DC.

[73] Robu, M. (2013) The Dynamic and Importance of SMES in Economy. USV Annals of Economics and Public Administration, 13, 84-89.

[74] Wright, J. (2013) Credit Unions: A Solution to Poor Bank Lending? Civitas, London.

[75] Quaye, I. and Sarbah, A. (2014) Assessing Alternative Sources of Financing for Small and Medium Scale Enterprises in Ghana Case Study of Savings and Loans Companies (S\&Ls) in the Greater Accra Region in Ghana. International Journal of Advancements in Research \& Technology, 3, 123-136.

[76] Sotunde, B. (2014) Ghana Establishes \$2.7m YES Fund for Young Entrepreneurs. ENTERPRISE54. 
[77] Delener, N. (1990) The Effects of Religious Factors on Perceived Risk in Durable Goods Purchase Decision. Journal of Consumer Marketing, 7, 27-38. http://dx.doi.org/10.1108/EUM0000000002580

[78] McDaniel, S.W. and Burnett, J.J. (1990) Consumer Religiosity and Retail Store Evaluative Criteria. Journal of the Academy of Marketing Science, 18, 101-112. http://dx.doi.org/10.1007/BF02726426

[79] Rashid, M.Z. and Ibrahim, S. (2008) The Effect of Culture and Religiosity on Business Ethics: A Cross-Cultural Comparison. Journal of Business Ethics, 82, 907-917. http://dx.doi.org/10.1007/s10551-007-9601-3

[80] Muhamad, N. and Mizerski, D. (2010) The Constructs Mediating Religions' Influence on Buyers and Consumers. Journal of Islamic Marketing, 1, 124-150. http://dx.doi.org/10.1108/17590831011055860

[81] Beer, W.L. (1960) Credit Unions \& the Church. The Japan Missionary Bulletin, 229-238.

[82] Graham, K. (2010) Credit Unions: What Can They Do for Your Money? HQ Financial Views, 5, 1-3.

[83] Stewardship (2010) Credit Unions: A Short Guide for Churches.

[84] Marshall, M.N. (1996) Sampling for Qualitative Research. Family Practice, 13, 522-526. http://dx.doi.org/10.1093/fampra/13.6.522

[85] O’brien, M.R. (2007) A Caution Regarding Rules of Thumb for Variance Inflation Factors. Quality \& Quantity, 41, 673-690. http://dx.doi.org/10.1007/s11135-006-9018-6

[86] Hair, J., Anderson, R., Tatham, R. and Black, W. (1995) Multivariate Data Analysis. Prentice-Hall, Upper Saddle River. 